\title{
Impairments in cognition and neural precursor cell proliferation in mice expressing constitutively active glycogen synthase kinase-3
}

\author{
Marta Pardo ${ }^{1+}$, Margaret K. King ${ }^{1+}$, Emma Perez-Costas ${ }^{2}$, Miguel Melendez-Ferro ${ }^{2}$, Ana Martinez ${ }^{3}$, \\ Eleonore Beurel ${ }^{1}$ and Richard S. Jope ${ }^{1 *}$
}

${ }^{1}$ Departments of Psychiatry and Behavioral Sciences and Biochemistry and Molecular Biology, Miller School of Medicine, University of Miami, Miami, FL, USA

${ }^{2}$ Department of Psychiatry, University of Alabama at Birmingham, Birmingham, AL, USA

${ }^{3}$ Centro de Investigaciones Biologicas-CSIC, Madrid, Spain

Edited by:

Valérie Doyère, CNRS, France

Reviewed by:

Djoher Nora Abrous, Institut des

Neurosciences de Bordeaux, France

Anna Klintsova, University of

Delaware, USA

*Correspondence:

Richard S. Jope, Departments of

Psychiatry and Behavioral Sciences and Biochemistry and Molecular

Biology, Miller School of Medicine,

University of Miami, 1011 NW 15th

Street, Gautier Building room 416,

Miami, FL 33136, USA

e-mail: rjope@med.miami.edu

${ }^{t}$ These authors have contributed equally to this work.
Brain glycogen synthase kinase-3 (GSK3) is hyperactive in several neurological conditions that involve impairments in both cognition and neurogenesis. This raises the hypotheses that hyperactive GSK3 may directly contribute to impaired cognition, and that this may be related to deficiencies in neural precursor cells (NPC). To study the effects of hyperactive GSK3 in the absence of disease influences, we compared adult hippocampal NPC proliferation and performance in three cognitive tasks in male and female wild-type (WT) mice and GSK3 knockin mice, which express constitutively active GSK3. NPC proliferation was $\sim 40 \%$ deficient in both male and female GSK3 knockin mice compared with WT mice. Environmental enrichment (EE) increased NPC proliferation in male, but not female, GSK3 knockin mice and WT mice. Male and female GSK3 knockin mice exhibited impairments in novel object recognition, temporal order memory, and coordinate spatial processing compared with gender-matched WT mice. EE restored impaired novel object recognition and temporal ordering in both sexes of GSK3 knockin mice, indicating that this repair was not dependent on NPC proliferation, which was not increased by EE in female GSK3 knockin mice. Acute $1 \mathrm{~h}$ pretreatment with the GSK3 inhibitor TDZD-8 also improved novel object recognition and temporal ordering in male and female GSK3 knockin mice. These findings demonstrate that hyperactive GSK3 is sufficient to impair adult hippocampal NPC proliferation and to impair performance in three cognitive tasks in both male and female mice, but these changes in NPC proliferation do not directly regulate novel object recognition and temporal ordering tasks.

Keywords: glycogen synthase kinase-3, neurogenesis, novel object recognition, spatial memory, environmental enrichment

\section{INTRODUCTION}

Cognitive deficits constitute a critical pathological feature that is difficult to treat in many psychiatric and neurological disorders, which have been suggested to be associated with impaired adult hippocampal neurogenesis (Leuner et al., 2006; Massa et al., 2011; King et al., 2014). Neurogenesis involves neural precursor cell (NPC) proliferation and differentiation into neurons, a process that has been linked to hippocampal-dependent cognitive processes (Kempermann, 2002; van Praag et al., 2005; Leuner et al., 2006; Deng et al., 2010; Massa et al., 2011). The potential coexistence of impairments in cognitive processes and hippocampal neurogenesis, for example in Alzheimer's disease (Mu and Gage, 2011), Fragile X syndrome (Guo et al., 2012), and mood disorders (Jacobs et al., 2000), raises the possibility that the two are linked. Thus, impaired neurogenesis in multiple disorders may contribute to cognitive deficits, and bolstering neurogenesis may provide a mechanism to improve learning and memory (Bruel-Jungerman et al., 2005; Jessberger et al., 2009).
The serine/threonine kinase glycogen synthase kinase-3 (GSK3) is a critical regulator of both cognition (King et al., 2014) and neurogenesis (Kim et al., 2009). GSK3 refers to two isoforms, GSK3 $\alpha$ and GSK3 $\beta$, that are primarily regulated by inhibitory phosphorylation on Ser21-GSK3 $\alpha$ and Ser9GSK3 $\beta$ (Jope and Johnson, 2004). The importance of inhibitory control of GSK3 can be studied using GSK3 $\alpha 21 \mathrm{~A} / 21 \mathrm{~A} / \beta 9 \mathrm{~A} / 9 \mathrm{~A}$ knockin mice (hereafter referred to as GSK3 KI mice), with the regulatory serines of both GSK3 isoforms mutated to alanines (McManus et al., 2005; Eom and Jope, 2009; Polter et al., 2010). These mutations maintain GSK3 maximally active within the physiological range, since both GSK3 isoforms are expressed at normal levels. Conversely, inhibition of GSK3 in healthy wild-type (WT) rodents generally has little effect on performance on cognitive tasks, but ameliorates cognitive impairments associated with a wide variety of injury and disease models in rodents (King et al., 2014). However, these effects of GSK3 inhibitors often are apparently due to actions 
involving attenuation of responses to the insult (King et al., 2014), leaving open the question of whether hyperactive GSK3 alone is sufficient to impair cognition. Abundant evidence has shown that GSK3 modulates adult hippocampal NPC proliferation, which is severely impaired in male GSK3 KI mice (Eom and Jope, 2009) and is increased by molecular deletion or inhibition of GSK3 (Chen et al., 2000; Hashimoto et al., 2003; Silva et al., 2008; Wexler et al., 2008; Kim et al., 2009; Morales-Garcia et al., 2012). These findings raise the hypothesis that hyperactive GSK3 may cause cognitive impairments and that these may be associated with impaired NPC proliferation.

Like GSK3, environmental enrichment (EE) also affects both cognition and components of neurogenesis in rodents. NPC proliferation is increased in male rodents exposed to $\mathrm{EE}$ or exercise, a key component of EE (Kempermann et al., 1997, 2002; Brown et al., 2003; Komitova et al., 2005; Rossi et al., 2006; Leal-Galicia et al., 2007; Zhao et al., 2008; Hu et al., 2010; Chakrabarti et al., 2011; Mustroph et al., 2012; Salmaso et al., 2012; Tanti et al., 2013). Unlike male mice, EE did not alter NPC proliferation in the hippocampus of female mice (Kempermann et al., 1997; van Praag et al., 1999; Brown et al., 2003; Westenbroek et al., 2004; Kobilo et al., 2011), supporting substantial evidence that male and female rodents differ in mechanisms influencing both cognition and NPC proliferation (Barha and Galea, 2010; Chow et al., 2013; Galea et al., 2013). EE has also been shown in many studies to increase performance of rodents in a multitude of cognitive tasks (Sale et al., 2014), including novel object recognition (O'Callaghan et al., 2007; Leal-Galicia et al., 2008; Doulames et al., 2014) and spatial processing (Schrijver et al., 2004; Doulames et al., 2014). Thus, EE may improve both cognition and NPC proliferation, raising the possibilities that these outcomes are linked and that EE may counteract impairments in these processes caused by hyperactive GSK3. Therefore, we used GSK3 KI mice to examine if hyperactive GSK3 is sufficient to impair hippocampal NPC proliferation and performance on three cognitive tasks: novel object recognition (Clark et al., 2000; Hunsaker et al., 2008; Antunes and Biala, 2012), a temporal order task (Kesner et al., 2004, 2005; Hunsaker et al., 2006), and a coordinate spatial processing task (GoodrichHunsaker et al., 2008; Hunsaker et al., 2008, 2012). We also tested if there were differences in male and female mice and if EE influenced these characteristics.

\section{MATERIALS AND METHODS \\ MICE}

Male and female adult (9-11 weeks old at the time of behavioral testing and NPC proliferation analysis) homozygous GSK $3 \alpha / \beta^{21 A / 21 A / 9 A / 9 A} \mathrm{KI}$ mice and matched WT mice were used (McManus et al., 2005). Inhibitory serine-phosphorylation of GSK3 $\alpha$ and GSK3 $\beta$ is absent in these mice, whereas the total levels of both GSK3 isoforms are equivalent to WT mice (Figure 1A). GSK3 KI mice develop and reproduce normally with no overt phenotype (McManus et al., 2005; Eom and Jope, 2009; Polter et al., 2010). Mice were housed in groups of 3-5 in standard cages in light and temperature controlled rooms and were treated in accordance with NIH and the University of Miami Institutional

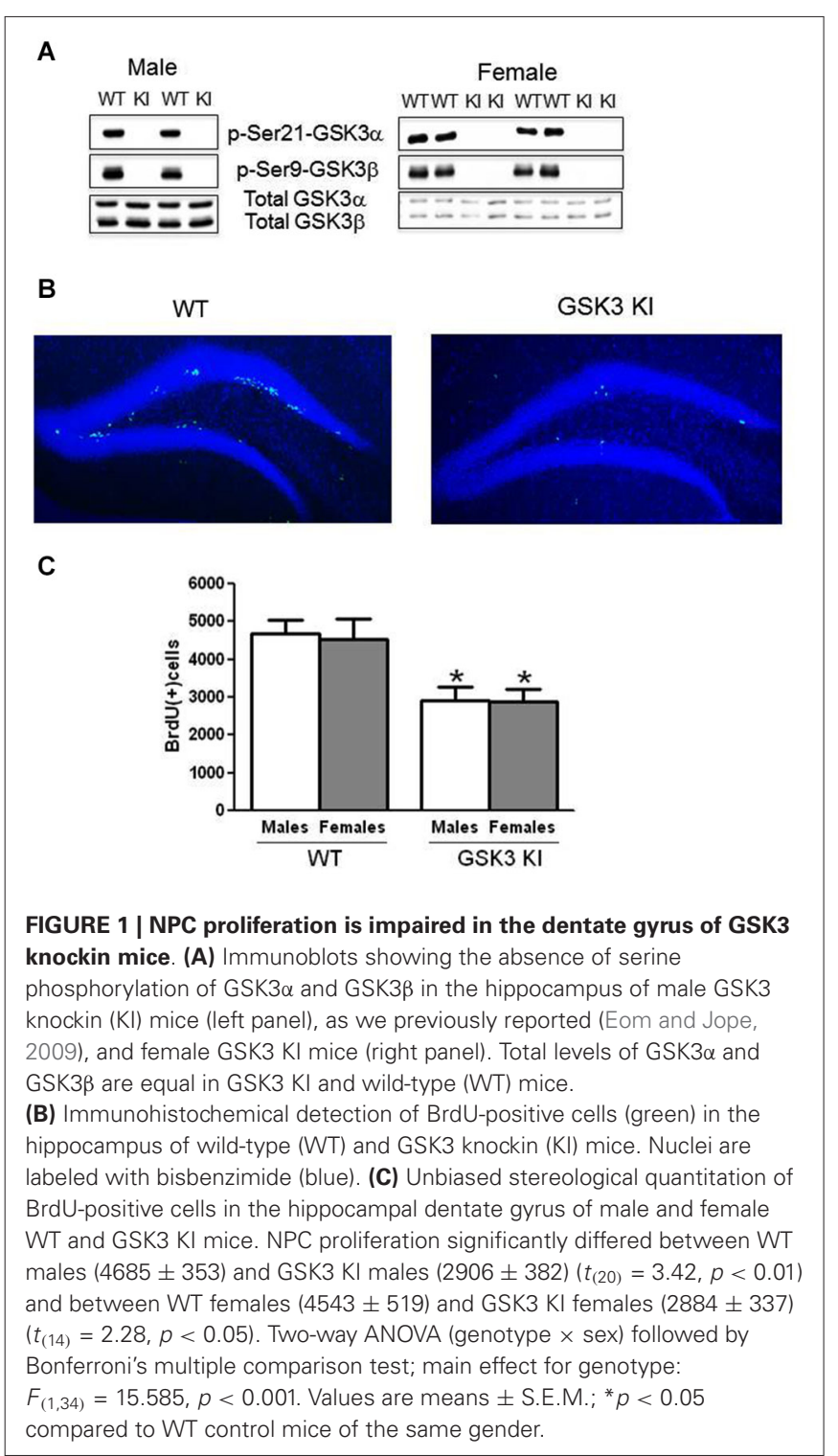

Animal Care and Use Committee regulations. Mice were treated intraperitoneally (i.p.) with vehicle or thiadiazolidindione-8 (TDZD-8; $5 \mathrm{mg} / \mathrm{kg}$ ), a selective non-ATP competitive inhibitor of GSK3 (Martinez et al., 2002), dissolved in 5\% Tween 80 and $5 \%$ DMSO in saline, $1 \mathrm{~h}$ prior to behavioral testing. For $\mathrm{EE}$, mice were housed in a large cage $(55 \mathrm{~cm} \times 32 \mathrm{~cm} \times$ $22 \mathrm{~cm}$ ) with extra wood chip bedding, nesting material, and a variety of sized, shaped, and colored objects for 25 days. Weekly the objects were washed and moved, and new objects were added.

\section{IMMUNOBLOT ANALYSIS}

Mouse hippocampi were rapidly dissected in ice-cold phosphatebuffered saline. Brain regions were homogenized in ice-cold lysis buffer containing $20 \mathrm{mM}$ Tris- $\mathrm{HCl}, \mathrm{pH} 7.4,150 \mathrm{mM}$ $\mathrm{NaCl}, 2 \mathrm{mM}$ EDTA, 1\% Triton X-100, 10\% glycerol, $1 \mu \mathrm{g} / \mathrm{ml}$ leupeptin, $1 \mu \mathrm{g} / \mathrm{ml}$ aprotinin, $1 \mu \mathrm{g} / \mathrm{ml}$ pepstatin, $1 \mathrm{mM}$ 
phenylmethanesulfonyl fluoride, $50 \mathrm{mM} \mathrm{NaF}, 1 \mathrm{mM}$ sodium orthovanadate, and $100 \mathrm{nM}$ okadaic acid. The lysates were centrifuged at $20,800 \times \mathrm{g}$ for $10 \mathrm{~min}$. Protein concentrations in the supernatants were determined using the Bradford protein assay (Bradford, 1976). Lysates were mixed with Laemmli sample buffer (2\% SDS) and placed in a boiling water bath for $5 \mathrm{~min}$. Proteins $(10 \mu \mathrm{g})$ were resolved in SDSpolyacrylamide gels, transferred to nitrocellulose, and incubated with primary antibodies to phospho-Ser9-GSK3 $\beta$ (1:1000; Cell Signaling Technology), phospho-Ser21-GSK3 $\alpha$ (1:1000; Cell Signaling Technology), and total GSK3 $\alpha / \beta$ (1:2000; Millipore). Immunoblots were developed using horseradish peroxidaseconjugated goat anti-mouse, or goat anti-rabbit IgG, followed by detection with enhanced chemiluminescence.

\section{MEASUREMENT OF HIPPOCAMPAL NPC PROLIFERATION}

5-Bromo-2'-deoxyuridine (BrdU; 100 mg/kg; Sigma-Aldrich, St Louis, MO) was administered i.p. three times at $2 \mathrm{~h}$ intervals, and mice were analyzed $24 \mathrm{~h}$ later, as we previously described (Eom and Jope, 2009). Mice were anesthetized and transcardially perfused with $0.9 \% \mathrm{NaCl}$ followed by $4 \%$ paraformaldehyde in $0.1 \mathrm{M}$ phosphate buffer ( $\mathrm{pH}$ 7.4). Brains were post-fixed overnight in $4 \%$ paraformaldehyde at $4^{\circ} \mathrm{C}$ and cryoprotected in $30 \%$ sucrose/phosphate buffered saline (PBS). Each brain was sliced coronally $(30 \mu \mathrm{m})$ with a microtome (Leica, Nubloch, Germany) through the rostrocaudal hippocampus and stored in PBS with $0.01 \%$ sodium azide. Every sixth section was analyzed for BrdU-specific immunohistochemistry as previously described (Eom and Jope, 2009). Sections were washed in 0.05 M Tris$\mathrm{HCl}$ buffer (TBS, $\mathrm{pH} 7.4$ ) and incubated in $1 \mathrm{~N} \mathrm{HCl}$ on ice for $10 \mathrm{~min}$, in $2 \mathrm{~N} \mathrm{HCl}$ for $10 \mathrm{~min}$ at room temperature, and in $2 \mathrm{~N} \mathrm{HCl}$ at $37^{\circ} \mathrm{C}$ for $20 \mathrm{~min}$, washed with $1 \mathrm{M}$ borate buffer, $\mathrm{pH} 8.5$, on ice, and rinsed in TBS. The sections were incubated with anti-BrdU antibody (1:500; BU1/75; Abcam) in $15 \%$ normal goat serum and TBS blocking buffer (1\% bovine serum albumin, $0.2 \%$ TritonX100 in TBS) for $20 \mathrm{~h}$ at $4^{\circ} \mathrm{C}$. Sections were washed with TBS and incubated with Alexa Fluor 488 goat anti-rat (1:200, Invitrogen) in 10\% normal goat serum and TBS blocking buffer for $2 \mathrm{~h}$ at room temperature in the dark. Cell nuclei were stained by incubating sections for $5 \mathrm{~min}$ in $0.2 \mu \mathrm{g} / \mathrm{ml}$ bisbenzimide (Hoechst 33258; Sigma). BrdU positive cells in the granule cell layer of the dentate gyrus and the subgranular zone were counted in each section and analyzed by unbiased stereology using the StereoInvestigator system (MicroBrightField, Williston, VT). To distinguish single cells within clusters, all counts were performed using a $63 \times$ oil immersion objective (Olympus BX-51), omitting cells in the outermost focal plane. The total number of BrdU-labeled cells per section was determined and multiplied by 6 to obtain the total number of cells per dentate gyrus. The parameters for the steorological study were the following: Section fraction 6; grid size $250 \times 90 \mu \mathrm{m}$; counting frame $40 \times 40 \mu \mathrm{m} ; \mathrm{CE}$ values were close to 0.1 in all experiments; previous analyses in biological structures have indicated that a CE near 0.1 is adequate to find a real difference in the number of objects counted between two different samples (Gundersen and Jensen, 1987; West, 1993).

\section{BEHAVIORAL ANALYSES}

For all behavioral assessments, mice were acclimated to the room containing the behavioral instruments for 30 min before testing, the sessions were filmed, a white noise generator $(55 \mathrm{~dB})$ was used, and each apparatus and object was cleaned with 70\% ethanol between each test session. Measures of novel object recognition, temporal ordering for visual objects (referred to as temporal order task), and coordinate spatial processing, were assessed by published methods (King and Jope, 2013; Franklin et al., 2014). Behavioral tests were conducted during 3 consecutive days, one test every $24 \mathrm{~h}$. For all cognitive assessments, time spent exploring an object included the mouse sniffing or touching the object with its nose, vibrissa, mouth, or forepaws. Time spent near or standing on top of an object without interacting with it was not counted as exploration.

The novel object recognition task was carried out in a fourstep procedure with male mice as previously described (Hoge and Kesner, 2007; Hunsaker et al., 2012; Franklin et al., 2014) and a two-step procedure for female mice because female WT mice had difficulty with the four-step procedure (see Section Discussion). For male mice, a Plexiglass box $(26 \mathrm{~cm}$ long $\times 20 \mathrm{~cm}$ wide $\times$ $16 \mathrm{~cm}$ tall) and four objects in duplicate $(4-6 \mathrm{~cm}$ diameter $\times$ 2-6 cm height) were used. Each mouse was allowed to explore two identical copies of Object 1 for $5 \mathrm{~min}$, rested for $5 \mathrm{~min}$ in an opaque holding container, and then allowed to explore two copies of Object 2 for $5 \mathrm{~min}$, followed by the same protocol for Object 3. For the test phase, each mouse was allowed to explore an unused copy of Object 1 and a novel Object 4 for $5 \mathrm{~min}$. More time spent exploring the novel Object 4 than the familiar Object 1 indicates normal memory processing. Time spent exploring each object was obtained from videos, and the exploration ratio was calculated as the times (exploring Object 4 - exploring Object 1)/(exploring Object 1 plus Object 4). For female mice, the procedure was identical to that described above except after exploring Object 1, mice were exposed to an unused copy of Object 1 and a novel Object 2 for $5 \mathrm{~min}$ for the test phase.

For the temporal order task, each mouse underwent three sessions to explore three new sets of objects (Objects 5, 6, 7). During the test session, the mouse was allowed to explore an unused copy of Object 5 and an unused copy of Object 7 for 5 min. Normal temporal order memory is exhibited by mice spending more time exploring the first object presented (Object 5) than the most recent object presented (Object 7). The exploration ratio was calculated as time (exploring Object 5 - exploring Object 7)/(exploring Object 5 plus Object 7).

For the coordinate spatial processing task, during the habituation stage each mouse was allowed to explore two novel objects that were $45 \mathrm{~cm}$ apart for $15 \mathrm{~min}$. After $5 \mathrm{~min}$ in an opaque holding container, each mouse was allowed to explore for $5 \mathrm{~min}$ the same two objects that had been moved closer together $(30 \mathrm{~cm})$. Mice that remember the distance between objects display increased exploration of the objects during the test session compared with the last $5 \mathrm{~min}$ of the habituation phase. The exploration ratio was calculated as time (exploring during the 5 min test session)/(exploring during the 5 min test session plus the last $5 \mathrm{~min}$ of the habituation session). 


\section{STATISTICAL ANALYSES}

Results were analyzed by one-way ANOVA with condition (genotype $\times$ treatment), two-way ANOVA with condition (genotype $\times$ sex), or three-way ANOVA with condition (genotype $\times$ sex $\times$ treatment) followed by Dunnett's test and Bonferroni's multiple comparison tests, or by Student's $t$-test where indicated.

\section{RESULTS \\ ADULT HIPPOCAMPAL NPC PROLIFERATION IS IMPAIRED IN MALE AND FEMALE GSK3 KI MICE}

Immunohistochemical analysis of BrdU-labeled cells demons -trated a predominant location in the subgranular zone of the dentate gyrus in both WT and GSK3 KI mice (Figure 1B). We previously reported that WT and GSK3 KI mouse brains displayed equivalent morphological features, hippocampal volumes, and staining for neuronal nuclei (NeuN) and glial fibrillary acidic protein (GFAP; Eom and Jope, 2009). As we reported previously (Eom and Jope, 2009), quantitative unbiased stereology analysis revealed that the number of BrdU-labeled cells within the dentate gyrus in male GSK3 KI mice was significantly 40\% lower than in matched WT mice (WT males: $4685 \pm 353$, GSK3 KI males: $2906 \pm 382 ; t_{(20)}=3.42, p<0.01$ ) (Figure 1C). We extended the analysis to female mice, which revealed a $40 \%$ deficit in NPC proliferation in female GSK3 KI mice compared with female WT mice (WT females: $4543 \pm 519$, GSK3 KI females: $\left.2884 \pm 338 ; t_{(14)}=2.28, p<0.05\right)$. Twoway ANOVA condition (genotype $\times$ sex) revealed a main effect for genotype $\left(F_{(1,34)}=15.585, p<0.001\right)$. There was no main effect for sex $\left(F_{(1,34)}=0.036, p=0.851\right)$, and there was no interaction between male and female WT mice or between male and female GSK3 KI mice $\left(F_{(1,34)}=0.019\right.$, $p=0.89$ ).

\section{COGNITION IS IMPAIRED IN MALE AND FEMALE GSK3 KI MICE}

We tested if male and female GSK3 KI mice displayed altered performance in three cognitive tasks compared with gendermatched WT mice: novel object recognition, temporal order memory, and coordinate spatial processing. In the novel object recognition test (Figure 2A), a measure of recognition memory, male WT mice spent significantly more time exploring the novel than the familiar object ( $25 \pm 5$ vs. $9 \pm 2 \mathrm{~s} ; t_{(18)}=3.14, p<0.01$ ). In contrast, male GSK3 KI mice did not display preference for the novel object $\left(11 \pm 1\right.$ vs. $\left.22 \pm 5 \mathrm{~s} ; t_{(22)}=2.057, p=0.052\right)$. The exploration ratio (Figure $2 \mathrm{~B}$ ) was significantly different between male WT mice $(0.41 \pm 0.12)$ and GSK3 KI mice $(-0.22 \pm 0.10$; $\left.t_{(20)}=3.84, p<0.01\right)$.

In the temporal order task (Figure 2C), a task used to assess episodic-like memory, male WT mice spent significantly more time exploring the first object presented, indicative of memory of the order the objects were presented (Object 5: $24 \pm 3$ vs. Object $\left.7: 10 \pm 3 s ; t_{(18)}=3.23, p<0.01\right)$. Male GSK3 KI mice displayed impaired ability to discriminate the presentation order, as they did not exhibit significant differences in time spent exploring each object (Object 5: $9 \pm 2$ vs. Object 7: $13 \pm 2 \mathrm{~s} ; t_{(22)}=1.17$, $p=0.25$ ). The exploration ratio (Figure $2 \mathrm{D}$ ) was significantly different between male WT mice $(0.49 \pm 0.09)$ and GSK3 KI mice $\left(-0.17 \pm 0.11 ; t_{(20)}=4.53, p<0.01\right)$.

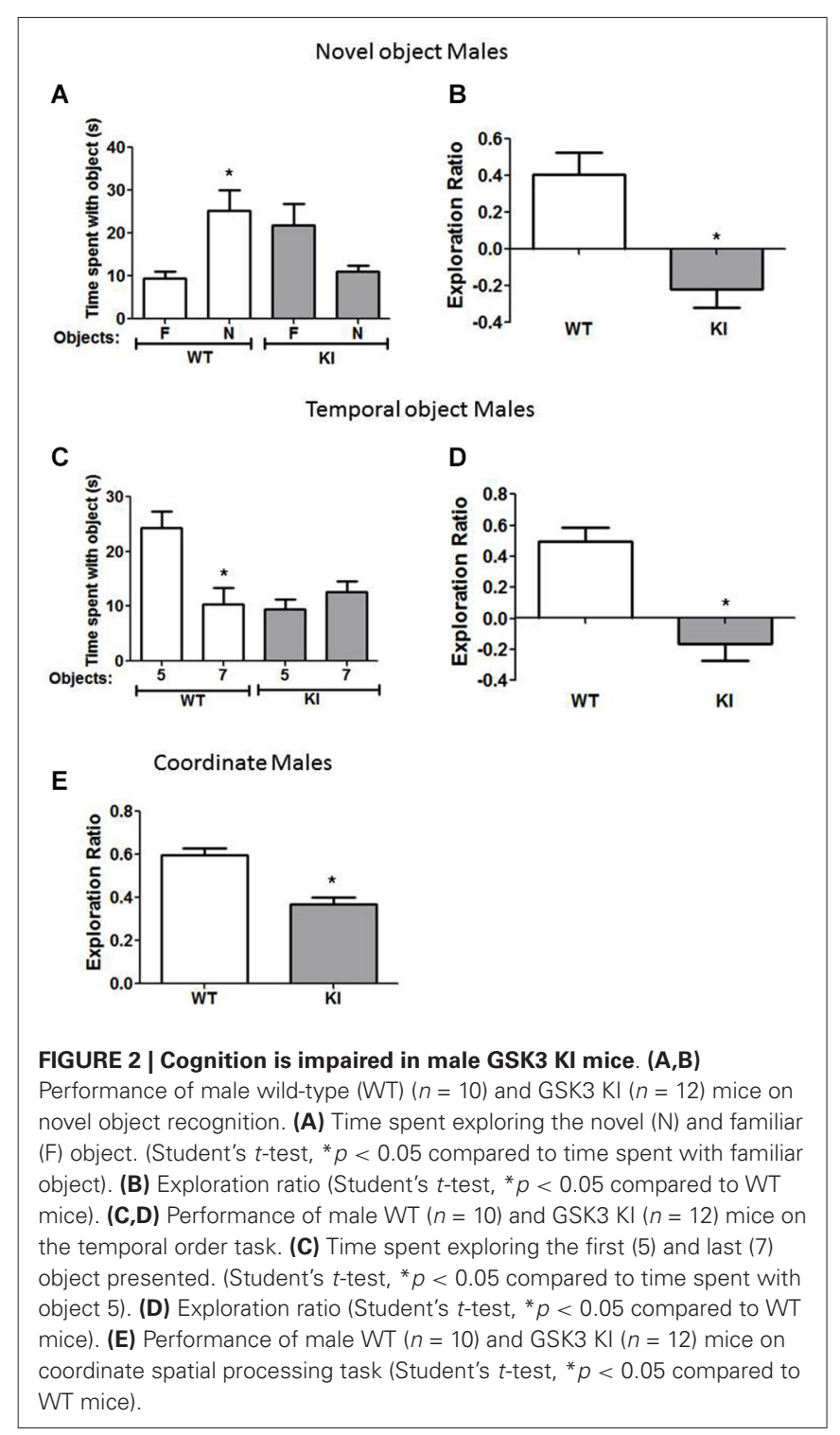

In the coordinate spatial processing task (Figure $2 \mathrm{E}$ ), a task developed for the measurement of spatial memory, male WT mice, but not male GSK3 KI mice, spent more time exploring objects during the testing period when the distance between objects was changed compared to the last $5 \mathrm{~min}$ of the habituation phase. Thus, there was a significant effect of genotype on the exploration ratio (WT: $0.60 \pm 0.03$ : KI: $0.37 \pm 0.03 ; t_{(20)}=5.34$, $p<0.01)$.

We also tested if female GSK3 KI mice displayed cognitive deficits similar to male GSK3 KI mice. In the novel object recognition task (Figure 3A), female WT mice spent significantly more time exploring the novel than the familiar object $(18 \pm 4$ vs. $\left.5 \pm 2 \mathrm{~s} ; t_{(18)}=3.02, p<0.05\right)$. In contrast, female GSK3 KI mice did not display preference for the novel object ( $15 \pm 3$ vs. 20 $\left.\pm 2 \mathrm{~s} ; t_{(16)}=1.89, p=0.08\right)$. The exploration ratio (Figure 3B) was significantly different between female WT mice $(0.54 \pm$ $0.14)$ and female GSK3 KI mice $\left(-0.16 \pm 0.09 ; t_{(17)}=4.07\right.$, $p<0.01)$. 


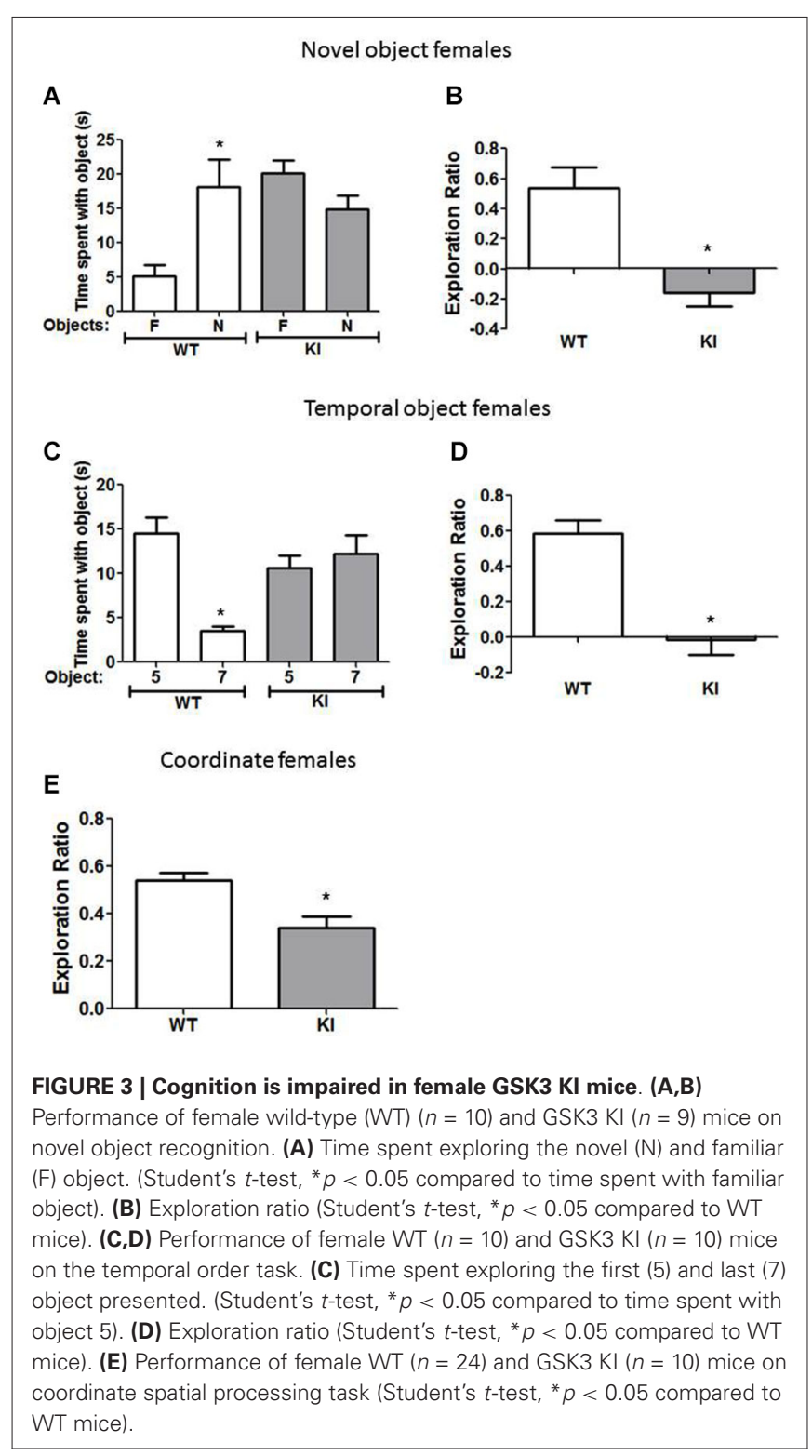

In the temporal object task (Figure 3C), female WT mice spent significantly more time exploring the first object presented (Object 5: $15 \pm 2$ vs. Object 7: $4 \pm 1 \mathrm{~s} ; t_{(18)}=5.74, p<0.01$ ). However, female GSK3 KI mice spent equivalent times exploring each object (Object 5: $11 \pm 1$ vs. Object 7: $12 \pm 2 \mathrm{~s} ; t_{(18)}=0.64$, $p=0.53$ ). The exploration ratio (Figure $3 \mathrm{D}$ ) was significantly different between female WT mice $(0.58 \pm 0.08)$ and female GSK3 KI mice $\left(-0.01 \pm 0.09 ; t_{(18)}=5.19, p<0.01\right)$.

In the coordinate spatial processing task (Figure 3E), female WT mice, but not female GSK3 KI mice, spent more time exploring objects during the testing period when the distance between objects was changed compared to the last $5 \mathrm{~min}$ of the habituation phase. Thus, there was a significant difference between genotypes in the exploration ratio (WT: $0.54 \pm 0.03$ : KI: $\left.0.34 \pm 0.05 ; t_{(32)}=3.28, p<0.01\right)$.

Overall, we found that constitutively active GSK3 in both male and female GSK3 KI mice caused significantly impaired performance in the novel object recognition task, the temporal order task, and coordinate spatial processing.

\section{MODULATION OF GSK3 AND HIPPOCAMPAL NPC PROLIFERATION BY EE}

We tested if EE affected the impaired NPC proliferation in GSK3 KI mice. Three-way ANOVA condition (genotype $\times$ sex $x$ treatment) followed by post hoc Bonferroni's multiple comparison test revealed a main effect for genotype $\left(F_{(1,63)}=20.406\right.$, $p<0.001)$, a main effect for sex $\left(F_{(1,63)}=14.238, p<0.001\right)$, and a main effect for treatment $\left(F_{(1,63)}=9.462, p<0.01\right)$. There was an interaction for sex $\times$ treatment $\left(F_{(1,63)}=12.522, p<0.01\right)$. EE significantly increased hippocampal NPC proliferation by $\sim 50 \%$ in male WT mice (WT control males: $4685 \pm 353$, WT EE males: $\left.7309 \pm 547 ; t_{(18)}=4.17, p<0.01\right)$ (Figure 4A), as previously reported (Komitova et al., 2005; Leal-Galicia et al., 2007; Zhao et al., 2008; Hu et al., 2010; Chakrabarti et al., 2011; Mustroph et al., 2012). Hippocampal NPC proliferation also was increased by EE in male GSK3 KI mice by $\sim 70 \%$ (GSK3 KI control males: $2906 \pm 382$; GSK3 KI EE males: $\left.4915 \pm 786, t_{(14)}=2.61, p<0.05\right)$. This increase restored proliferation to the level of control male WT mice, but NPC proliferation after EE remained 30\% below that of EE-treated male WT mice. Thus, although constitutively active GSK3 impairs basal adult hippocampal NPC proliferation, it does not block enhancement induced by EE in male mice, indicating that the increase induced by EE is independent of GSK3 inhibition by serine phosphorylation.

Female mice differed from male mice in that EE did not significantly increase hippocampal NPC proliferation in female WT mice (WT control females: $4543 \pm 519$, WT EE females: $3800 \pm 447 ; t_{(18)}=1.09, p=0.29$ ) (Figure 4B), as reported previously (Kempermann et al., 1997; van Praag et al., 1999; Li et al., 2008). EE also did not significantly increase hippocampal NPC proliferation in female GSK3 KI mice (GSK3 KI control females: $2884 \pm 338$, GSK3 KI EE females: $\left.3303 \pm 449 ; t_{(13)}=0.62, p=0.55\right)$, although the small differences after EE eliminated the statistically significant deficit in NPC proliferation compared with female WT mice.

\section{EFFECTS OF EE AND TDZD-8 ON COGNITIVE TASKS IN MALE MICE}

We tested if EE or acute inhibition of GSK3 altered performance of male mice on cognitive tasks. In the novel object recognition test (Figure 5A), EE did not significantly alter the preference of male WT mice for the novel object (control: familiar $36 \pm 5$ vs. novel $64 \pm 5 \%$ of total time exploring objects; $t_{(18)}=3.99$, $p<0.01$; EE: familiar $27 \pm 8$ vs. novel $73 \pm 8 \%$ of total time exploring objects; $t_{(18)}=4.00, p<0.01$ ) or the exploration ratio (control $0.29 \pm 0.10$ vs. EE $0.46 \pm 0.16 ; t_{(18)}=0.90, p=0.38$ ) $($ Figure 5B). There was a significant effect (genotype $\times$ treatment; $\left.F_{(4,55)}=4.71 ; p<0.01\right)$ on the exploration ratio. EE normalized the preference of male GSK3 KI mice for the novel object (control: familiar $61 \pm 5$ vs. novel $39 \pm 5 \%$ of total time exploring objects; EE: familiar $37 \pm 6$ vs. novel $63 \pm 6 \%$ of total time exploring objects; $t_{(26)}=3.17, p<0.01$ ), and normalized the exploration ratio (GSK3 KI: control: $-0.22 \pm 0.10$ vs. EE: $0.25 \pm 0.11$; 

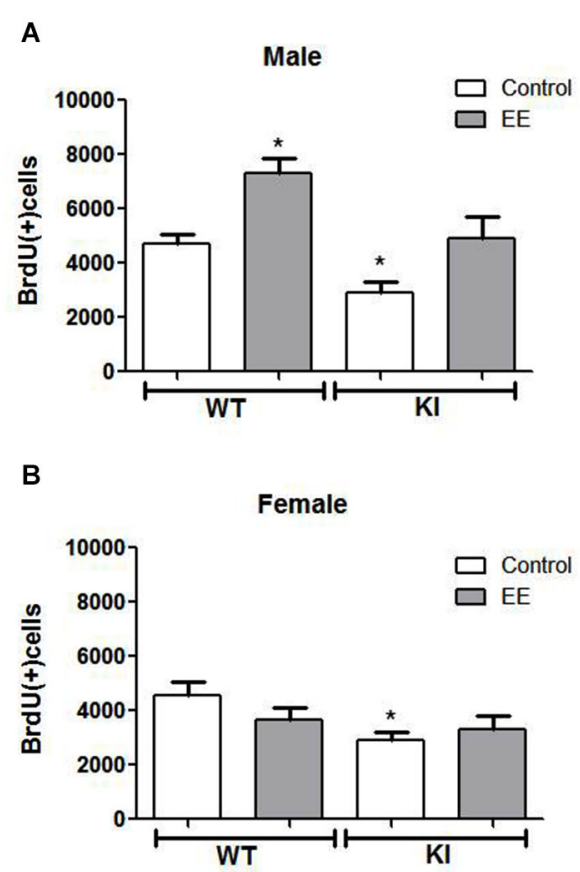

FIGURE 4 | Effects of environmental enrichment (EE) on NPC proliferation in the dentate gyrus. Unbiased stereological quantitation of BrdU-positive cells in the hippocampal dentate gyrus of male and female wild-type (WT) (control males $n=11$, EE males $n=9$, control females $n=10$, EE females $n=10$ ) and GSK3 knockin (KI) (control males $n=11$, EE males $n=5$, control females $n=6$, EE females $n=9$ ) mice with and without 25 days of EE. Three-way ANOVA (condition: genotype $\times$ sex $\times$ treatment) revealed a main effect for sex: $\left.F_{(1,63)}=14.238, p<0.001\right)$; main effect for genotype: $\left.F_{(1,63)}=20.406, p<0.001\right)$; main effect for treatment $\left.F_{(1,63)}=9.462, p<0.01\right)$; interaction for sex $\times$ treatment: $F_{(1,63)}=12.522$, $p<0.01$ ); and no other interactions. (A) NPC proliferation was significantly increased by EE in male WT mice (WT control males: $4685 \pm 353$; WT EE males: $7309 \pm 547$ ) and male GSK3 KI mice (KI control males: $2906 \pm 382$; KI EE males: $4915 \pm 786)$. (B) NPC proliferation was unchanged by EE in female WT mice (WT control females: $4543 \pm 519$; WT EE females: $3800 \pm$ 447) and female GSK3 KI mice (KI control females: $2884 \pm 338, \mathrm{KI} E \mathrm{E}$ females: $3303 \pm 499$ ). Values are means \pm S.E.M.; ${ }^{*} p<0.05$ compared to control WT mice.

$\left.t_{(24)}=3.09, p<0.01\right)$ (Figure 5B). Administration of the GSK3 inhibitor TDZD-8 $(5 \mathrm{mg} / \mathrm{kg}) 1 \mathrm{~h}$ prior to testing rescued the impairment in novel object recognition in male GSK3 KI mice (novel $63 \pm 4$ vs. familiar $37 \pm 4 \%$ of total time exploring objects; $\left.t_{(28)}=4.24, p<0.05\right)$ and the impaired exploration ratio increased to a level not significantly different from male WT mice (GSK3 KI TDZD: $0.27 \pm 0.11$ vs. WT control: $0.30 \pm 0.10$; $\left.t_{(19)}=0.25, p=0.80\right)$. We previously reported that novel object recognition in WT mice is unaltered by acute administration of two GSK3 inhibitors, TDZD-8 and VP0.7 (Franklin et al., 2014).

In the temporal order memory task, EE did not alter the performance of male WT mice (Figures 5C,D). There was a significant effect (genotype $\times$ treatment; $F_{(4,64)}=5.22 ; p<0.01$ ) on the exploration ratio. In male GSK3 KI mice, EE normalized object preferences to WT levels (Object 5: $67 \pm 5$, Object 7: 33 $\pm 5 \%$ of total time exploring objects; $t_{(24)}=4.48, p<0.01$,

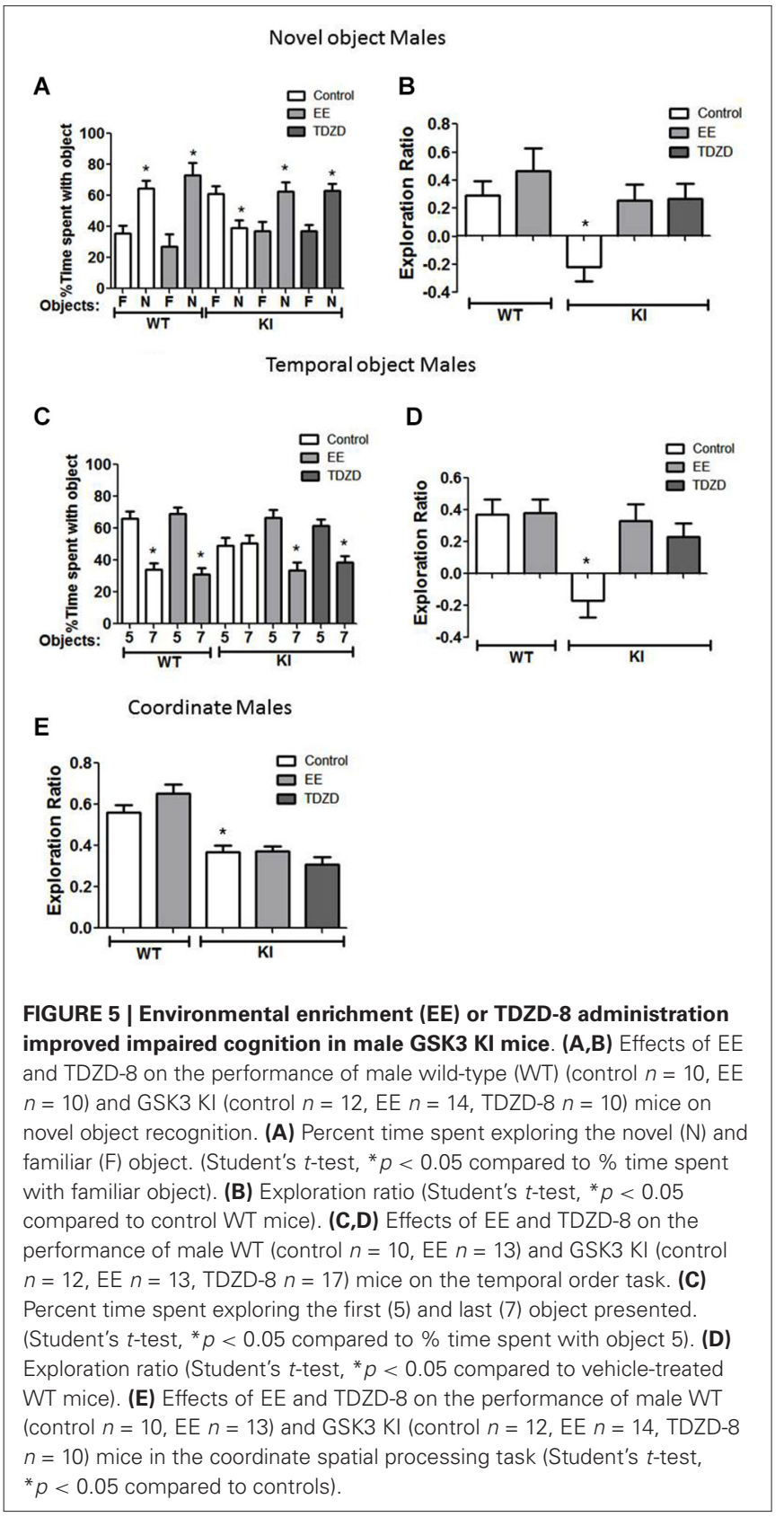

Figure 5C), which raised the exploration ratio to that of WT mice (control: $-0.17 \pm 0.11$ vs. EE $0.33 \pm 0.10 ; t_{(23)}=3.32, p<0.01$ ). TDZD-8 administration redirected the exploratory behavior of the male GSK3 KI mice towards the object presented first (Object 5: $61 \pm 4$ vs. Object 7: $39 \pm 4 \%$ of total time exploring objects; $\left.t_{(32)}=3.84, p<0.01\right)$ and restored the exploration ratio (control: $-0.17 \pm 0.11$ vs. TDZD $\left.0.23 \pm 0.08 ; t_{(27)}=2.94, p<0.01\right)$ to a level that did not significantly differ from male WT mice $(p=0.48)$.

In the coordinate spatial processing task (Figure 5E), there was a significant effect (genotype $\times$ treatment; $F_{(4,58)}=18.24$; $p<0.01$ ). EE had no significant effect on the exploration ratio in male WT mice (control $0.56 \pm 0.03$ vs. EE $0.65 \pm 0.04 ; t_{(21)}=1.53$ 
$p=14$ ) or GSK3 KI mice (control $0.37 \pm 0.03$ vs. EE $0.37 \pm 0.02$; $t_{(24)}=0.09, p=0.93$ ). Interestingly, TDZD- 8 treatment also did not restore impaired coordinate spatial processing in male GSK3 $\mathrm{KI}$ mice (control $0.37 \pm 0.03$ vs. TDZD $0.31 \pm 0.03 ; t_{(22)}=1.53$, $p=0.14)$.

\section{EFFECTS OF EE AND TDZD-8 ON COGNITIVE TASKS IN FEMALE MICE}

Cognitive behaviors were also examined in female mice after treatment with EE and TDZD-8. There was a significant effect (genotype $\times$ treatment; $F_{(4,44)}=7.41 ; p<0.01$ ) between conditions. The impaired novel object recognition in female GSK3 KI mice was repaired by EE (Figure 6A) (familiar 32 \pm 4 vs. novel $68 \pm 4 \%$ of total time exploring objects; $\left.t_{(16)}=6.55, p<0.01\right)$ and $\mathrm{EE}$ increased the exploration ratio (Figure 6B) to a level similar to female WT mice (GSK3 KI EE: $0.35 \pm 0.08$ vs. WT control: $0.54 \pm 0.14 ; t_{(17)}=1.12$, $p=0.28)$. Administration of TDZD-8 restored impaired novel object recognition in female GSK3 KI mice (Figure 6A), resulting in significantly more time spent exploring the novel than familiar object (familiar $24 \pm 5$ vs. novel $76 \pm 5 \%$ of total time exploring objects; $t_{(16)}=7.41, p<0.01$ ), and significantly increased the impaired exploration ratio (Figure 6B) to a level equivalent to female WT mice (GSK3 KI TDZD: $0.52 \pm 0.10$ vs. WT control: $0.54 \pm 0.14 ; t_{(17)}=0.07$, $p=0.95)$.

With GSK3 KI female mice in the temporal order memory task (Figure 6C), there was a significant effect between experimental conditions $\left(F_{(4,56)}=2.93, p<0.05\right)$. EE increased the time female GSK3 KI mice spent exploring the object presented first (Object 5: $69 \pm 5$ vs. Object 7: $31 \pm 5 \%$ of total time exploring objects; $\left.t_{(26)}=5.44, p<0.01\right)$, so the exploration ratio did not differ from that of female WT mice (WT control $0.41 \pm 0.07$ vs. GSK3 KI EE $0.37 \pm 0.10 ; t_{(26)}=0.30$, $p=0.77$ ) (Figure 6D). EE did not alter the exploration ratio of female WT mice (control $0.41 \pm 0.07$ vs. EE $0.43 \pm$ $\left.0.15 ; t_{(22)}=0.13, p=0.90\right)$. After TDZD-8 administration, female GSK3 KI mice explored the first object presented significantly longer than the last object presented (Object 5: 68 \pm 5 vs. Object 7: $32 \pm 5 \%$ of total time exploring objects; $\left.t_{(16)}=5.10, p<0.01\right)$ and the exploration ratio increased (control $-0.01 \pm 0.09$ vs. TDZD $0.37 \pm 0.10 ; t_{(17)}=2.86$, $p<0.05)$ to a value that did not differ from female WT mice $(p=0.74)$.

As with male GSK3 KI mice, there was a significant effect (genotype $\times$ treatment; $F_{(4,73)}=7.31 ; p<0.01$ ) on the exploration ratio. The impairment in coordinate spatial processing in female GSK3 KI mice (Figure 6E) was unaltered by EE (control $0.34 \pm$ 0.05 vs. EE $\left.0.39 \pm 0.04 ; t_{(23)}=0.71, p=0.49\right)$. TDZD-8 treatment caused a slight increase in the exploration ratio of female GSK3 KI mice (GSK3 KI: control $0.34 \pm 0.05$ vs. TDZD $0.44 \pm 0.05$; $\left.t_{(17)}=0.16, p=0.16\right)$, resulting in an exploration ratio that was not significantly different from female WT mice (WT control 0.54 \pm 0.03 vs. GSK3 KI TDZD $\left.0.44 \pm 0.05 ; t_{(31)}=1.58, p=0.12\right)$.

\section{DISCUSSION}

Hyperactive GSK3 contributes to pathological processes in animal models of a disparate group of diseases that involve impaired

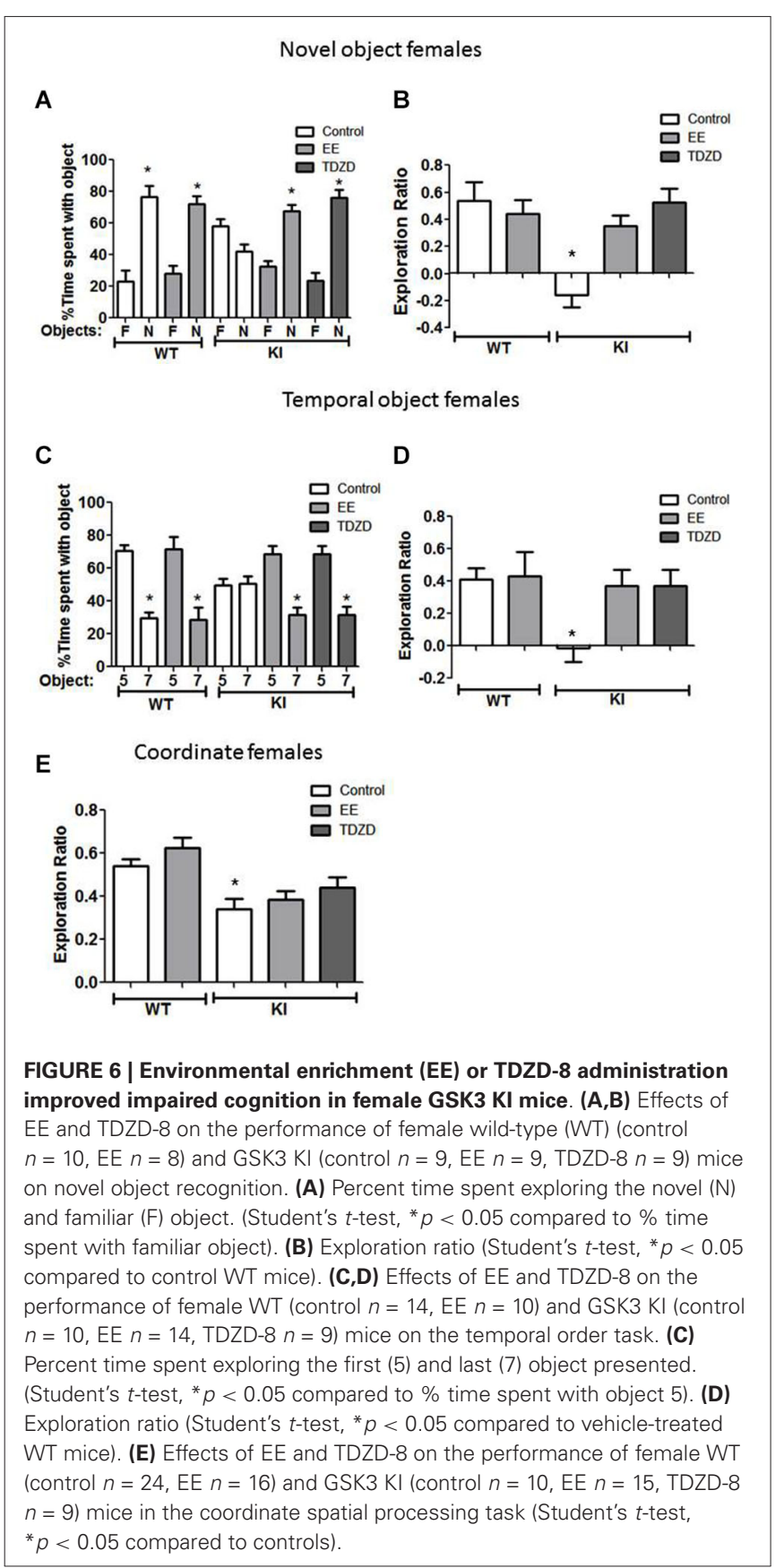

cognition, such as Alzheimer's disease (Martinez and Perez, 2008; Avila et al., 2010), mood disorders (O'Brien and Klein, 2009; Jope, 2011), and Fragile X syndrome (Mines and Jope, 2011). Conversely, administration of GSK3 inhibitors ameliorates cognitive impairments in multiple conditions (King et al., 2014). However, it is not clear if cognitive impairments result directly from hyperactive GSK3 or from actions of GSK3 promoting pathological processes, such as promoting protein aggregates in mouse models of Alzheimer's disease (King et al., 2014). Here we used GSK3 KI mice, which express constitutively active GSK3, to test if increased GSK3 activity is sufficient to impair cognitive processes in mice without associated pathology (McManus et al., 
2005; Eom and Jope, 2009). We found that GSK3 KI mice have severe deficits in three cognitive assessments, novel object recognition, temporal order memory, and coordinate spatial processing, that were as severe as recently found in the mouse model of Fragile X syndrome (King and Jope, 2013; Franklin et al., 2014). These cognitive impairments in GSK3 KI mice affected both sexes, and were significantly improved by housing mice in EE and by acute treatment with a GSK3 inhibitor. Both sexes of GSK3 KI mice also displayed impaired adult hippocampal NPC proliferation, but changes effected by EE and TDZD-8 indicate that deficits in NPC proliferation did not cause the impairments in novel object recognition or temporal ordering.

The finding that female GSK3 KI mice exhibit impaired hippocampal NPC proliferation compared to female WT mice extends previous findings indicating that GSK3 can regulate this process. These include reports that NPC proliferation is impaired by constitutively active GSK3 in male GSK3 KI mice (Eom and Jope, 2009), molecular deletion of GSK3 in mouse neural progenitors increased neurogenesis (Kim et al., 2009), and neurogenesis is increased by treatment with lithium or other drugs that inhibit GSK3 (Chen et al., 2000; Hashimoto et al., 2003; Silva et al., 2008; Wexler et al., 2008; Kim et al., 2009; Mao et al., 2009; Serenó et al., 2009; Fiorentini et al., 2010; Guo et al., 2012; Morales-Garcia et al., 2012; Contestabile et al., 2013). Housing male, but not female, WT mice in EE led to increased hippocampal NPC proliferation. These results are in accordance with previous reports that $\mathrm{EE}$ increases hippocampal neurogenesis in male WT mice (Komitova et al., 2005; Leal-Galicia et al., 2007; Duman et al., 2008; Greenwood and Fleshner, 2008; Zhao et al., 2008; Hu et al., 2010; Chakrabarti et al., 2011; Jha et al., 2011), but not in female mice (Kempermann et al., 1997; van Praag et al., 1999; Brown et al., 2003; Westenbroek et al., 2004; Kobilo et al., 2011). Extending the analysis to GSK3 KI mice demonstrated that EE increased hippocampal NPC proliferation in male GSK3 KI mice by the same percentage as in male WT mice. This demonstrates that inhibitory serine-phosphorylation of GSK3 is not required for EE to enhance hippocampal NPC proliferation. This differs from the requirement for serinephosphorylation of GSK3 for treatment with lithium and fluoxetine to increase hippocampal NPC proliferation (Eom and Jope, 2009). Hippocampal NPC proliferation was not affected by EE in female GSK3 knockin mice, demonstrating that there are sex differences in the influence of the environment on hippocampal NPC proliferation in both WT mice and in mice in which GSK3 is hyperactive. The differential effects of EE on hippocampal NPC proliferation in male and female GSK3 KI mice provided a mechanism to determine if this process is required for EE-induced improvements in performance in several cognitive tasks without the need to use toxic interventions to ablate NPC proliferation.

Novel object recognition is a measure of recognition memory that assesses the ability of mice to recognize previously encountered objects by determining their propensity to explore a novel object more than a familiar object (Antunes and Biala, 2012). Novel object recognition has been reported to be a task both independent of the hippocampus (Winters et al., 2004, 2008; Winters and Bussey, 2005; Dere et al., 2007; Hunsaker and Kesner, 2008) and hippocampal-dependent (Clark et al., 2000; Hunsaker et al., 2008; Dewachter et al., 2009; Fortress et al., 2013; Franklin et al., 2014). Novel object recognition was severely impaired in male GSK3 KI mice compared to male WT mice. This finding extends a previous report that male GSK3 $\beta$ KI mice display impaired novel object recognition (Dewachter et al., 2009). Upon assessment of novel object recognition in female WT mice, we found them unable to differentiate between the novel and familiar objects in the paradigm used with male mice. Previous comparisons of sexes in novel object recognition reported no differences (Benice et al., 2006), or superior performance of females (Podhorna and Brown, 2002; Sutcliffe et al., 2007) or of males (Frick and Gresack, 2003). Because of this complication in assessing female mice, we used a simpler procedure for female mice than for male mice in which female WT mice successfully displayed novel object recognition. With this protocol, we found that female GSK3 knockin mice displayed a severe deficit in novel object recognition compared with female WT mice. Previous studies have reported that performance on the novel object recognition test was enhanced in parallel with increased hippocampal NPC proliferation in response to exercise (Bechara and Kelly, 2013), by lithium treatment of mice modeling Down syndrome (Contestabile et al., 2013), or by EE in rat models of global ischemia (Kato et al., 2014) or type 1 diabetes (Piazza et al., 2011). Conversely, concurrent impairments in novel object recognition and NPC proliferation have been reported after a number of insults (Graciarena et al., 2010; Nam et al., 2013; Chen et al., 2014; Greene-Schloesser et al., 2014). We found that housing mice in EE improved novel object recognition in both male and female GSK3 KI mice. However, EE only increased hippocampal NPC proliferation in male GSK3 KI mice, not female GSK3 KI mice, indicating that EE-induced improved novel object recognition can occur independently of increased NPC proliferation. Furthermore, treatment with the GSK3 inhibitor TDZD- 8 for $1 \mathrm{~h}$, a time too short to functionally alter NPC proliferation, also improved novel object recognition in both male and female GSK3 KI mice. Thus, constitutively active GSK3 impaired both novel object recognition and hippocampal NPC proliferation in both male and female GSK3 KI mice, but novel object recognition could be repaired independently of NPC proliferation. We suggest that impaired novel object recognition in GSK3 KI mice may be linked to deficient LTP, which requires inhibition of GSK3 (Hooper et al., 2007; Peineau et al., 2007; Dewachter et al., 2009; Franklin et al., 2014).

The temporal order task assesses episodic-like memory in mice based on their preference to explore an object that was presented earlier in time than an object that was more recently explored (Dere et al., 2005a,b; Hoge and Kesner, 2007), and is reported to be dependent on the hippocampal CA1 region (Kesner et al., 2004, 2005; Hunsaker et al., 2006; Hoge and Kesner, 2007). Temporal order recognition was significantly impaired in both male and female GSK3 KI mice compared with gender-matched WT mice. EE ameliorated impaired temporal order recognition in both male and female GSK3 KI mice. Improvements in temporal 
order object recognition were unrelated to increased hippocampal NPC proliferation since the latter occurred only in male, but not female, GSK3 KI mice, and acute TDZD- 8 pretreatment restored temporal order recognition in both sexes. Normalization by acute treatment with GSK3 inhibitors of impaired temporal order recognition in a mouse model of Fragile $\mathrm{X}$ syndrome in which GSK3 is hyperactive was previously suggested to involve improved function of the hippocampal trisynaptic circuit, although this remains to be tested (King and Jope, 2013; Franklin et al., 2014).

The coordinate spatial processing task assesses hippocampusdependent spatial memory in mice based on their ability to recognize a change in the metric of the environment by comparing the exploration time between the end of the habituation period and a period when the distance between objects was changed (Galani et al., 1998; Goodrich-Hunsaker et al., 2005, 2008). Coordinate spatial memory was severely impaired in male and female GSK3 KI mice compared with gender-matched WT mice. EE did not modify coordinate spatial memory in any group of mice, suggesting that this process is independent of hippocampal NPC proliferation, which was increased by EE in male GSK3 KI mice. The impairment that male and female GSK3 KI mice displayed in this spatial task also was not improved by acute TDZD-8 pretreatment. Previous studies have described concurrent enhanced spatial memory and increased NPC proliferation after EE (Okun et al., 2010; Li et al., 2011; Kato et al., 2014), and concurrent impaired spatial memory and impaired NPC proliferation (Umka et al., 2010; Li et al., 2013; Nam et al., 2013; Ambrée et al., 2014; Chen et al., 2014; Greene-Schloesser et al., 2014; Valero et al., 2014). However, studies of the dependence of cognitive behaviors on NPC proliferation have often relied on correlations or have used NPC-ablating approaches, whereas in the present study EE was used to increase NPC proliferation. The results found here agree with previous findings that adult hippocampal neurogenesis is not obligatory for certain forms of learning and memory (Jaholkowski et al., 2009; Groves et al., 2013), and with their suggestion that studies using NPC-ablating approaches, such as irradiation, drug treatments, or mutant mice, may be confounded by other actions that could interfere with the interpretation of the results.

Interactions between genetics and the environment may have tremendous influences on susceptibilities to cognitive impairments in many diseases. However, much still remains to be learned about factors that mediate differences in susceptibility and severity of cognitive impairments. This study examined the combinatorial effects of genetics (gender, hyperactive GSK3) and the environment (EE) to determine factors that mediate differences in cognition in mice. Expression of maximally active GSK3 in GSK3 KI mice was sufficient to impair performance in three cognitive tasks, and these impairments were equivalent in male and female GSK3 KI mice. Thus, hyperactive GSK3, which occurs in several conditions displaying impairments in cognition, is sufficient to impair cognition, further supporting previous reports that GSK3 inhibitors may alleviate cognitive impairments in a number of conditions (King et al., 2014).

\section{FUNDING}

Grant sponsor: NIMH; Grant numbers: MH038752, MH090236.

\section{ACKNOWLEDGMENTS}

We thank Dr. Tae-Yeon Eom, Dr. Ling Song, Dr. Iria GonzalezDopeso Reyes, Matthew Rice, Dr. Terry Lewis, and Dr. Cora M. Taylor for their generous technical advice, and Dr. George McNamara and Dr. Melissa Carballosa-Gonzalez for their help with fluorescent microscopy.

\section{REFERENCES}

Ambrée, O., Buschert, J., Zhang, W., Arolt, V., Dere, E., and Zlomuzica, A. (2014). Impaired spatial learning and reduced adult hippocampal neurogenesis in histamine H1-receptor knockout mice. Eur. Neuropsychopharmacol. 24, 1394-1404. doi: 10.1016/j.euroneuro.2014.04.006

Antunes, M., and Biala, G. (2012). The novel object recognition memory: neurobiology, test procedure and its modifications. Cogn. Process. 13, 93-110. doi: 10.1007/s10339-011-0430-z

Avila, J., Wandosell, F., and Hernández, F. (2010). Role of glycogen synthase kinase3 in Alzheimer's disease pathogenesis and glycogen synthase kinase- 3 inhibitors. Expert. Rev. Neurother. 10, 703-710. doi: 10.1586/ern.10.40

Barha, C. K., and Galea, L. A. (2010). Influence of different estrogens on neuroplasticity and cognition in the hippocampus. Biochim. Biophys. Acta 1800, 1056-1067. doi: 10.1016/j.bbagen.2010.01.006

Bechara, R. G., and Kelly, Á. M. (2013). Exercise improves object recognition memory and induces BDNF expression and cell proliferation in cognitively enriched rats. Behav. Brain Res. 245, 96-100. doi: 10.1016/j.bbr.2013.02.018

Benice, T. S., Rizk, A., Kohama, S., Pfankuch, T., and Raber, J. (2006). Sexdifferences in age-related cognitive decline in C57BL/6J mice associated with increased brain microtubule-associated protein 2 and synaptophysin immunoreactivity. Neuroscience 137, 413-423. doi: 10.1016/j.neuroscience. 2005.08.029

Bradford, M. M. (1976). A rapid and sensitive method for the quantitation of microgram quantities of protein utilizing the principle of protein-dye binding. Anal. Biochem. 72, 248-254. doi: 10.1006/abio.1976.9999

Brown, J., Cooper-Kuhn, C. M., Kempermann, G., Van Praag, H., Winkler, J., Gage, F. H., et al. (2003). Enriched environment and physical activity stimulate hippocampal but not olfactory bulb neurogenesis. Eur. J. Neurosci. 17, 2042-2046. doi: 10.1046/j.1460-9568.2003.02647.x

Bruel-Jungerman, E., Laroche, S., and Rampon, C. (2005). New neurons in the dentate gyrus are involved in the expression of enhanced long-term memory following environmental enrichment. Eur. J. Neurosci. 21, 513-521. doi: 10. 1111/j.1460-9568.2005.03875.x

Chakrabarti, L., Scafidi, J., Gallo, V., and Haydar, T. F. (2011). Environmental enrichment rescues postnatal neurogenesis defect in the male and female Ts65Dn mouse model of down syndrome. Dev. Neurosci. 33, 428-441. doi: 10. $1159 / 000329423$

Chen, W., Cheng, X., Chen, J., Yi, X., Nie, D., Sun, X., et al. (2014). Lycium barbarum polysaccharides prevent memory and neurogenesis impairments in scopolamine-treated rats. PLoS One 9:e88076. doi: 10.1371/journal.pone. 0088076

Chen, G., Rajkowska, G., Du, F., Seraji-Bozorgzad, N., and Manji, H. K. (2000). Enhancement of hippocampal neurogenesis by lithium. J. Neurochem. 75, 1729-1734. doi: 10.1046/j.1471-4159.2000.0751729.x

Chow, C., Epp, J. R., Lieblich, S. E., Barha, C. K., and Galea, L. A. (2013). Sex differences in neurogenesis and activation of new neurons in response to spatial learning and memory. Psychoneuroendocrinology 38, 1236-1250. doi: 10.1016/j. psyneuen.2012.11.007

Clark, R. E., Zola, S. M., and Squire, L. R. (2000). Impaired recognition memory in rats after damage to the hippocampus. J. Neurosci. 20, 8853-8860.

Contestabile, A., Greco, B., Ghezzi, D., Tucci, V., Benfenati, F., and Gasparini, L. (2013). Lithium rescues synaptic plasticity and memory in down syndrome mice. J. Clin. Invest. 123, 348-361. doi: 10.1172/JCI64650

Deng, W., Aimone, J. B., and Gage, F. H. (2010). New neurons and new memories: how does adult hippocampal neurogenesis affect learning and memory? Nat. Rev. Neurosci. 11, 339-350. doi: 10.1038/nrn2822 
Dere, E., Huston, J. P., and De Souza Silva, M. A. (2005a). Episodic-like memory in mice: simultaneous assessment of object, place and temporal order memory. Brain Res. Brain Res. Protoc. 16, 10-19. doi: 10.1016/j.brainresprot.2005. 08.001

Dere, E., Huston, J. P., and De Souza Silva, M. A. (2005b). Integrated memory for objects, places and temporal order: evidence for episodic-like memory in mice. Neurobiol. Learn. Mem. 84, 214-221. doi: 10.1016/j.nlm.2005.07.002

Dere, E., Huston, J. P., and De Souza Silva, M. A. (2007). The pharmacology, neuroanatomy and neurogenetics of one-trial object recognition in rodents. Neurosci. Biobehav. Rev. 31, 673-704. doi: 10.1016/j.neubiorev.2007.01.005

Dewachter, I., Ris, L., Jaworski, T., Seymour, C. M., Kremer, A., Borghgraef, P., et al. (2009). GSK3 $\beta$, a centre-staged kinase in neuropsychiatric disorders, modulates long term memory by inhibitory phosphorylation at serine-9. Neurobiol. Dis. 35, 193-200. doi: 10.1016/j.nbd.2009.04.003

Doulames, V., Lee, S., and Shea, T. B. (2014). Environmental enrichment and social interaction improve cognitive function and decrease reactive oxidative species in normal adult mice. Int. J. Neurosci. 124, 369-376. doi: 10.3109/00207454.2013. 848441

Duman, C. H., Schlesinger, L., Russell, D. S., and Duman, R. S. (2008). Voluntary exercise produces antidepressant and anxiolytic behavioral effects in mice. Brain Res. 1199, 148-158. doi: 10.1016/j.brainres.2007.12.047

Eom, T. Y., and Jope, R. S. (2009). Blocked inhibitory serine-phosphorylation of glycogen synthase kinase- $3 \alpha / \beta$ impairs in vivo neural precursor cell proliferation. Biol. Psychiatry 66, 494-502. doi: 10.1016/j.biopsych.2009.04.015

Fiorentini, A., Rosi, M. C., Grossi, C., Luccarini, I., and Casamenti, F. (2010). Lithium improves hippocampal neurogenesis, neuropathology and cognitive functions in APP mutant mice. PLoS One 5:e14382. doi: 10.1371/journal.pone. 0014382

Fortress, A. M., Schram, S. L., Tuscher, J. J., and Frick, K. M. (2013). Canonical Wnt signaling is necessary for object recognition memory consolidation. J. Neurosci. 33, 12619-12626. doi: 10.1523/JNEUROSCI.0659-13.2013

Franklin, A. V., King, M. K., Palomo, V., Martinez, A., McMahon, L., and Jope, R. S. (2014). Glycogen synthase kinase-3 inhibitors reverse deficits in longterm potentiation and cognition in Fragile X mice. Biol. Psychiatry 75, 198-206. doi: 10.1016/j.biopsych.2013.08.003

Frick, K. M., and Gresack, J. E. (2003). Sex differences in the behavioral response to spatial and object novelty in adult C57BL/6 mice. Behav. Neurosci. 117, 1283-1291. doi: 10.1037/0735-7044.117.6.1283

Galani, R., Weiss, I., Cassel, J. C., and Kelche, C. (1998). Spatial memory, habituation and reactions to spatial and nonspatial changes in rats with selective lesions of the hippocampus, the entorhinal cortex or the subiculum. Behav. Brain Res. 96, 1-12. doi: 10.1016/s0166-4328(97)00197-6

Galea, L. A., Wainwright, S. R., Roes, M. M., Duarte-Guterman, P., Chow, C., and Hamson, D. K. (2013). Sex, hormones and neurogenesis in the hippocampus: hormonal modulation of neurogenesis and potential functional implications. J. Neuroendocrinol. 25, 1039-1061. doi: 10.1111/jne.12070

Goodrich-Hunsaker, N. J., Hunsaker, M. R., and Kesner, R. P. (2005). Dissociating the role of the parietal cortex and dorsal hippocampus for spatial information processing. Behav. Neurosci. 119, 1307-1315. doi: 10.1037/0735-7044.119. 5.1307

Goodrich-Hunsaker, N. J., Hunsaker, M. R., and Kesner, R. P. (2008). The interactions and dissociations of the dorsal hippocampus subregions: how the dentate gyrus, CA3 and CA1 process spatial information. Behav. Neurosci. 122, 16-26. doi: 10.1037/0735-7044.122.1.16

Graciarena, M., Depino, A. M., and Pitossi, F. J. (2010). Prenatal inflammation impairs adult neurogenesis and memory related behavior through persistent hippocampal TGF $\beta 1$ downregulation. Brain Behav. Immun. 24, 1301-1309. doi: 10.1016/j.bbi.2010.06.005

Greene-Schloesser, D., Payne, V., Peiffer, A. M., Hsu, F. C., Riddle, D. R., Zhao, W., et al. (2014). The peroxisomal proliferator-activated receptor (PPAR) $\alpha$ agonist, fenofibrate, prevents fractionated whole-brain irradiation-induced cognitive impairment. Radiat. Res. 181, 33-44. doi: 10.1667/RR13202.1

Greenwood, B. N., and Fleshner, M. (2008). Exercise, learned helplessness and the stress-resistant brain. Neuromolecular Med. 10, 81-98. doi: 10.1007/s12017-0088029-y

Groves, J. O., Leslie, I., Huang, G. J., McHugh, S. B., Taylor, A., Mott, R., et al. (2013). Ablating adult neurogenesis in the rat has no effect on spatial processing: evidence from a novel pharmacogenetic model. PLoS Genet. 9:e1003718. doi: 10. 1371/journal.pgen.1003718
Gundersen, H. J., and Jensen, E. B. (1987). The efficiency of systematic sampling in stereology and its prediction. J. Microsc. 147, 229-263. doi: 10.1111/j.1365-2818. 1987.tb02837.x

Guo, W., Murthy, A. C., Zhang, L., Johnson, E. B., Schaller, E. G., Allan, A. M., et al. (2012). Inhibition of GSK3 $\beta$ improves hippocampus-dependent learning and rescues neurogenesis in a mouse model of fragile X syndrome. Hum. Mol. Genet. 21, 681-691. doi: 10.1093/hmg/ddr501

Hashimoto, R., Senatorov, V., Kanai, H., Leeds, P., and Chuang, D. M. (2003). Lithium stimulates progenitor proliferation in cultured brain neurons. Neuroscience 117, 55-61. doi: 10.1016/s0306-4522(02)00577-8

Hoge, J., and Kesner, R. P. (2007). Role of CA3 and CA1 subregions of the dorsal hippocampus on temporal processing of objects. Neurobiol. Learn. Mem. 88, 225-231. doi: 10.1016/j.nlm.2007.04.013

Hooper, C., Markevich, V., Plattner, F., Killick, R., Schofield, E., Engel, T., et al. (2007). Glycogen synthase kinase-3 inhibition is integral to longterm potentiation. Eur. J. Neurosci. 25, 81-86. doi: 10.1111/j.1460-9568.2006. 05245.x

Hu, Y. S., Xu, P., Pigino, G., Brady, S. T., Larson, J., and Lazarov, O. (2010). Complex environment experience rescues impaired neurogenesis, enhances synaptic plasticity and attenuates neuropathology in familial Alzheimer's diseaselinked APPswe/PS1DeltaE9 mice. FASEB J. 24, 1667-1681. doi: 10.1096/fj.09136945

Hunsaker, M. R., and Kesner, R. P. (2008). Evaluating the differential roles of the dorsal dentate gyrus, dorsal CA3, and dorsal CA1 during a temporal ordering for spatial locations task. Hippocampus 18, 955-964. doi: 10.1002/hipo. 20455

Hunsaker, M. R., Kim, K., Willemsen, R., and Berman, R. F. (2012). CGG trinucleotide repeat length modulates neural plasticity and spatiotemporal processing in a mouse model of the fragile $\mathrm{X}$ premutation. Hippocampus 22, 2260-2275. doi: 10.1002/hipo.22043

Hunsaker, M. R., Rosenberg, J. S., and Kesner, R. P. (2008). The role of the dentate gyrus, CA3a,b and CA3c for detecting spatial and environmental novelty. Hippocampus 18, 1064-1073. doi: 10.1002/hipo.20464

Hunsaker, M. R., Thorup, J. A., Welch, T., and Kesner, R. P. (2006). The role of CA3 and CA1 in the acquisition of an object-trace place paired associate task. Behav. Neurosci. 120, 1252-1256. doi: 10.1037/0735-7044.120.6.1252

Jacobs, B. L., van Praag, H., and Gage, F. H. (2000). Adult brain neurogenesis and psychiatry: a novel theory of depression. Mol. Psychiatry 5, 262-269. doi: 10. 1038/sj.mp.4000712

Jaholkowski, P., Kiryk, A., Jedynak, P., Ben Abdallah, N. M., Knapska, E., Kowalczyk, A., et al. (2009). New hippocampal neurons are not obligatory for memory formation; cyclin D2 knockout mice with no adult brain neurogenesis show learning. Learn. Mem. 16, 439-451. doi: 10.1101/lm.1459709

Jessberger, S., Clark, R. E., Broadbent, N. J., Clemenson, G. D. Jr., Consiglio, A., Lie, D. C., et al. (2009). Dentate gyrus-specific knockdown of adult neurogenesis impairs spatial and object recognition memory in adult rats. Learn. Mem. 16, 147-154. doi: 10.1101/lm.1172609

Jha, S., Dong, B., and Sakata, K. (2011). Enriched environment treatment reverses depression- like behavior and restores reduced hippocampal neurogenesis and protein levels of brain-derived neurotrophic factor in mice lacking its expression through promoter IV. Transl. Psychiatry 1:e40. doi: 10.1038/tp. 2011.33

Jope, R. S. (2011). Glycogen synthase kinase-3 in the etiology and treatment of mood disorders. Front. Mol. Neurosci. 4:16. doi: 10.3389/fnmol.2011.00016

Jope, R. S., and Johnson, G. V. W. (2004). The glamour and gloom of glycogen synthase kinase-3. Trends Biochem. Sci. 29, 95-102. doi: 10.1016/j.tibs.2003. 12.004

Kato, T., Eriguchi, T., Fujiwara, N., Murata, Y., Yoshino, A., Sakatani, K., et al. (2014). Effects of enriched environment on hippocampal neuronal cell death and neurogenesis in rat global ischemia. Adv. Exp. Med. Biol. 812, 203-208. doi: 10.1007/978-1-4939-0620-8_27

Kempermann, G. (2002). Why new neurons? Possible functions for adult hippocampal neurogenesis. J. Neurosci. 22, 635-638.

Kempermann, G., Gast, D., and Gage, F. H. (2002). Neuroplasticity in old age: sustained fivefold induction of hippocampal neurogenesis by long-term environmental enrichment. Ann. Neurol. 52, 135-143. doi: 10.1002/ana.10262

Kempermann, G., Kuhn, H. G., and Gage, F. H. (1997). More hippocampal neurons in adult mice living in an enriched environment. Nature 386, 493-495. doi: 10. $1038 / 386493 \mathrm{a} 0$ 
Kesner, R. P., Hunsaker, M. R., and Gilbert, P. E. (2005). The role of CA1 in the acquisition of an object- trace-odor paired associate task. Behav. Neurosci. 119, 781-786. doi: 10.1037/0735-7044.119.3.781

Kesner, R. P., Lee, I., and Gilbert, P. E. (2004). A behavioral assessment of hippocampal function based on a subregional analysis. Rev. Neurosci. 15, 333-351. doi: 10.1515/revneuro.2004.15.5.333

Kim, W. Y., Wang, X., Wu, Y., Doble, B. W., Patel, S., Woodgett, J. R., et al. (2009). GSK-3 is a master regulator of neural progenitor homeostasis. Nat. Neurosci. 12, 1390-1397. doi: 10.1038/nn.2408

King, M. K., and Jope, R. S. (2013). Lithium treatment alleviates impaired cognition in a mouse model of fragile X syndrome. Genes Brain Behav. 12, 723-731. doi: 10.1111/gbb.12071

King, M. K., Pardo, M., Cheng, Y., Downey, K., Jope, R. S., and Beurel, E. (2014). Glycogen synthase kinase-3 inhibitors: rescuers of cognitive impairments. Pharmacol. Ther. 141, 1-12. doi: 10.1016/j.pharmthera.2013.07.010

Kobilo, T., Liu, Q. R., Gandhi, K., Mughal, M., Shaham, Y., and van Praag, H. (2011). Running is the neurogenic and neurotrophic stimulus in environmental enrichment. Learn. Mem. 18, 605-609. doi: 10.1101/lm.2283011

Komitova, M., Mattsson, B., Johansson, B. B., and Eriksson, P. S. (2005). Enriched environment increases neural stem/progenitor cell proliferation and neurogenesis in the subventricular zone of stroke-lesioned adult rats. Stroke 36, 1278-1282. doi: 10.1161/01.str.0000166197.94147.59

Leal-Galicia, P., Castañeda-Bueno, M., Quiroz-Baez, R., and Arias, C. (2008). Longterm exposure to environmental enrichment since youth prevents recognition memory decline and increases synaptic plasticity markers in aging. Neurobiol. Learn. Mem. 90, 511-518. doi: 10.1016/j.nlm.2008.07.005

Leal-Galicia, P., Saldívar-González, A., Morimoto, S., and Arias, C. (2007). Exposure to environmental enrichment elicits differential hippocampal cell proliferation: role of individual responsiveness to anxiety. Dev. Neurobiol. 67, 395-405. doi: 10.1002/dneu.20322

Leuner, B., Gould, E., and Shors, T. J. (2006). Is there a link between adult neurogenesis and learning? Hippocampus 16, 216-224. doi: 10.1002/hipo. 20153

Li, Y. F., Cheng, Y. F., Huang, Y., Conti, M., Wilson, S. P., O’Donnell, J. M., et al. (2011). Phosphodiesterase-4D knock-out and RNA interference-mediated knock-down enhance memory and increase hippocampal neurogenesis via increased cAMP signaling. J. Neurosci. 31, 172-183. doi: 10.1523/JNEUROSCI. 5236-10.2011

Li, E., Kim, Y., Kim, S., and Park, S. (2013). Ghrelin-induced hippocampal neurogenesis and enhancement of cognitive function are mediated independently of GH/IGF-1 axis: lessons from the spontaneous dwarf rats. Endocr. J. 60, 1065-1075. doi: 10.1507/endocrj.ej13-0045

Li, Y., Luikart, B. W., Birnbaum, S., Chen, J., Kwon, C. H., Kernie, S. G., et al. (2008). TrkB regulates hippocampal neurogenesis and governs sensitivity to antidepressive treatment. Neuron 59, 399-412. doi: 10.1016/j.neuron.2008. 06.023

Mao, Y., Ge, X., Frank, C. L., Madison, J. M., Koehler, A. N., Doud, M. K., et al. (2009). Disrupted in schizophrenia 1 regulates neuronal progenitor proliferation via modulation of GSK3beta/beta-catenin signaling. Cell 136 1017-1031. doi: 10.1016/j.cell.2008.12.044

Martinez, A., Alonso, M., Castro, A., Pérez, C., and Moreno, F. J. (2002). First non-ATP competitive glycogen synthase kinase 3 beta (GSK-3 $\beta$ ) inhibitors: thiadiazolidinones (TDZD) as potential drugs for the treatment of Alzheimer's disease. J. Med. Chem. 45, 1292-1299. doi: 10.1021/jm011020u

Martinez, A., and Perez, D. I. (2008). GSK-3 inhibitors: a ray of hope for the treatment of Alzheimer's disease? J. Alzheimers Dis. 15, 181-191.

Massa, F., Koehl, M., Wiesner, T., Grosjean, N., Revest, J. M., Piazza, P. V., et al. (2011). Conditional reduction of adult neurogenesis impairs bidirectional hippocampal synaptic plasticity. Proc. Natl. Acad. Sci. U S A 108, 6644-6649. doi: 10.1073/pnas.1105938108

McManus, E. J., Sakamoto, K., Armit, L. J., Ronaldson, L., Shpiro, N., Marquez, R., et al. (2005). Role that phosphorylation of GSK3 plays in insulin and Wnt signalling defined by knockin analysis. EMBO J. 24, 1571-1583. doi: 10.1038/sj. emboj.7600633

Mines, M. A., and Jope, R. S. (2011). Glycogen synthase kinase-3: a promising therapeutic target for fragile x syndrome. Front. Mol. Neurosci. 4:35. doi: 10. 3389/fnmol.2011.00035

Morales-Garcia, J. A., Luna-Medina, R., Alonso-Gil, S., Sanz-Sancristobal, M., Palomo, V., Gil, C., et al. (2012). Glycogen synthase kinase 3 inhibition promotes adult hippocampal neurogenesis in vitro and in vivo. ACS Chem. Neurosci. 3 963-971. doi: 10.1021/cn300110c

$\mathrm{Mu}$, Y., and Gage, F. H. (2011). Adult hippocampal neurogenesis and its role in Alzheimer's disease. Mol. Neurodegener. 6:85. doi: 10.1186/17501326-6-85

Mustroph, M. L., Chen, S., Desai, S. C., Cay, E. B., DeYoung, E. K., and Rhodes, J. S. (2012). Aerobic exercise is the critical variable in an enriched environment that increases hippocampal neurogenesis and water maze learning in male C57BL/6J mice. Neuroscience 219, 62-71. doi: 10.1016/j.neuroscience.2012. 06.007

Nam, S. M., Choi, J. H., Yoo, D. Y., Kim, W., Jung, H. Y., Kim, J. W., et al. (2013). Valeriana officinalis extract and its main component, valerenic acid, ameliorate D-galactose-induced reductions in memory, cell proliferation and neuroblast differentiation by reducing corticosterone levels and lipid peroxidation. Exp. Gerontol. 48, 1369-1377. doi: 10.1016/j.exger.2013.09.002

O'Brien, W. T., and Klein, P. S. (2009). Validating GSK3 as an in vivo target of lithium action. Biochem. Soc. Trans. 37, 1133-1138. doi: 10.1042/BST0371133

O'Callaghan, R. M., Ohle, R., and Kelly, A. M. (2007). The effects of forced exercise on hippocampal plasticity in the rat: a comparison of LTP, spatial- and nonspatial learning. Behav. Brain Res. 176, 362-366. doi: 10.1016/j.bbr.2006.10.018

Okun, E., Griffioen, K., Barak, B., Roberts, N. J., Castro, K., Pita, M. A., et al. (2010). Toll-like receptor 3 inhibits memory retention and constrains adult hippocampal neurogenesis. Proc. Natl. Acad. Sci. U S A 107, 15625-15630. doi: $10.1073 /$ pnas. 1005807107

Peineau, S., Taghibiglou, C., Bradley, C., Wong, T. P., Liu, L., Lu, J., et al. (2007). LTP inhibits LTD in the hippocampus via regulation of GSK3 $\beta$. Neuron 53, 703-717. doi: 10.1016/j.neuron.2007.01.029

Piazza, F. V., Pinto, G. V., Trott, G., Marcuzzo, S., Gomez, R., and Fernandes Mda, C. (2011). Enriched environment prevents memory deficits in type 1 diabetic rats. Behav. Brain Res. 217, 16-20. doi: 10.1016/j.bbr.2010.09.017

Podhorna, J., and Brown, R. E. (2002). Strain differences in activity and emotionality do not account for differences in learning and memory performance between C57BL/6 and DBA/2 mice. Genes Brain Behav. 1, 96-110. doi: 10.1034/j.1601-183x.2002.10205.x

Polter, A., Beurel, E., Garner, R., Song, L., Miller, C., Sweatt, J. D., et al. (2010) Deficiency in the inhibitory serine-phosphorylation of glycogen synthase kinase-3 increases sensitivity to mood disturbances. Neuropsychopharmacology 35, 1761-1774. doi: 10.1038/npp.2010.43

Rossi, C., Angelucci, A., Costantin, L., Braschi, C., Mazzantini, M., Babbini, F., et al. (2006). Brain-derived neurotrophic factor (BDNF) is required for the enhancement of hippocampal neurogenesis following environmental enrichment. Eur. J. Neurosci. 24, 1850-1856. doi: 10.1111/j.1460-9568.2006. 05059.x

Sale, A., Berardi, N., and Maffei, L. (2014). Environment and brain plasticity: towards an endogenous pharmacotherapy. Physiol. Rev. 94, 189-234. doi: 10. 1152/physrev.00036.2012

Salmaso, N., Silbereis, J., Komitova, M., Mitchell, P., Chapman, K., Ment, L. R., et al. (2012). Environmental enrichment increases the GFAP+ stem cell pool and reverses hypoxia-induced cognitive deficits in juvenile mice. J. Neurosci. 32, 8930-8939. doi: 10.1523/JNEUROSCI.1398-12.2012

Schrijver, N. C., Pallier, P. N., Brown, V. J., and Würbel, H. (2004). Double dissociation of social and environmental stimulation on spatial learning and reversal learning in rats. Behav. Brain Res. 152, 307-314. doi: 10.1016/j.bbr.2003. 10.016

Serenó, L., Coma, M., Rodríguez, M., Sánchez-Ferrer, P., Sánchez, M. B., Gich, I., et al. (2009). A novel GSK-3beta inhibitor reduces Alzheimer's pathology and rescues neuronal loss in vivo. Neurobiol. Dis. 35, 359-367. doi: 10.1016/j.nbd. 2009.05.025

Silva, R., Mesquita, A. R., Bessa, J., Sousa, J. C., Sotiropoulos, I., Leão, P., et al. (2008). Lithium blocks stress-induced changes in depressive-like behavior and hippocampal cell fate: the role of glycogen-synthase-kinase-3 $\beta$. Neuroscience 152, 656-669. doi: 10.1016/j.neuroscience.2007.12.026

Sutcliffe, J. S., Marshall, K. M., and Neill, J. C. (2007). Influence of gender on working and spatial memory in the novel object recognition task in the rat. Behav. Brain Res. 177, 117-125. doi: 10.1016/j.bbr.2006.10.029

Tanti, A., Westphal, W. P., Girault, V., Brizard, B., Devers, S., Leguisquet, A. M., et al. (2013). Region-dependent and stage-specific effects of stress, environmental enrichment and antidepressant treatment on hippocampal neurogenesis. Hippocampus 23, 797-811. doi: 10.1002/hipo.22134 
Umka, J., Mustafa, S., ElBeltagy, M., Thorpe, A., Latif, L., Bennett, G., et al. (2010). Valproic acid reduces spatial working memory and cell proliferation in the hippocampus. Neuroscience 166, 15-22. doi: 10.1016/j.neuroscience.2009. 11.073

Valero, J., Mastrella, G., Neiva, I., Sánchez, S., and Malva, J. O. (2014). Long-term effects of an acute and systemic administration of LPS on adult neurogenesis and spatial memory. Front. Neurosci. 8:83. doi: 10.3389/fnins.2014.00083

van Praag, H., Kempermann, G., and Gage, F. H. (1999). Running increases cell proliferation and neurogenesis in the adult mouse dentate gyrus. Nat. Neurosci. 2, 266-270. doi: 10.1038/6368

van Praag, H., Shubert, T., Zhao, C., and Gage, F. H. (2005). Exercise enhances learning and hippocampal neurogenesis in aged mice. J. Neurosci. 25, 86808685. doi: 10.1523/jneurosci.1731-05.2005

West, M. J. (1993). New stereological methods for counting neurons. Neurobiol. Aging 14, 275-285. doi: 10.1016/0197-4580(93)90112-o

Westenbroek, C., Den Boer, J. A., Veenhuis, M., and Ter Horst, G. J. (2004). Chronic stress and social housing differentially affect neurogenesis in male and female rats. Brain Res. Bull. 64, 303-308. doi: 10.1016/j.brainresbull.2004. 08.006

Wexler, E. M., Geschwind, D. H., and Palmer, T. D. (2008). Lithium regulates adult hippocampal progenitor development through canonical Wnt pathway activation. Mol. Psychiatry 13, 285-292. doi: 10.1038/sj.mp.4002093

Winters, B. D., and Bussey, T. J. (2005). Glutamate receptors in perirhinal cortex mediate encoding, retrieval, and consolidation of object recognition memory. $J$. Neurosci. 25, 4243-4251. doi: 10.1523/jneurosci.0480-05.2005

Winters, B. D., Forwood, S. E., Cowell, R. A., Saksida, L. M., and Bussey, T. J. (2004). Double dissociation between the effects of peri-postrhinal cortex and hippocampal lesions on tests of object recognition and spatial memory: heterogeneity of function within the temporal lobe. J. Neurosci. 24, 5901-5908. doi: 10.1523/jneurosci.1346-04.2004

Winters, B. D., Saksida, L. M., and Bussey, T. J. (2008). Object recognition memory: neurobiological mechanisms of encoding, consolidation and retrieval. Neurosci. Biobehav. Rev. 32, 1055-1070. doi: 10.1016/j.neubiorev.2008.04.004

Zhao, C., Deng, W., and Gage, F. (2008). Mechanisms and functional implications of adult neurogenesis. Cell 132, 645-660. doi: 10.1016/j.cell.2008.01.033

Conflict of Interest Statement: The authors declare that the research was conducted in the absence of any commercial or financial relationships that could be construed as a potential conflict of interest.

Received: 25 November 2014; accepted: 13 February 2015; published online: 04 March 2015.

Citation: Pardo M, King MK, Perez-Costas E, Melendez-Ferro M, Martinez A, Beurel E and Jope RS (2015) Impairments in cognition and neural precursor cell proliferation in mice expressing constitutively active glycogen synthase kinase-3. Front. Behav. Neurosci. 9:55. doi: 10.3389/fnbeh.2015.00055

This article was submitted to the journal Frontiers in Behavioral Neuroscience.

Copyright (C) 2015 Pardo, King, Perez-Costas, Melendez-Ferro, Martinez, Beurel and Jope. This is an open-access article distributed under the terms of the Creative Commons Attribution License (CC BY). The use, distribution and reproduction in other forums is permitted, provided the original author(s) or licensor are credited and that the original publication in this journal is cited, in accordance with accepted academic practice. No use, distribution or reproduction is permitted which does not comply with these terms. 